\title{
The Influence of Psychological Empowerment on Turnover Intention through Appreciative Inquiry Workshop for Employee at Division X Company X
}

\author{
Ajeng Wilutantri ${ }^{\mathrm{a}}$ and Arum Etikariena ${ }^{\mathrm{b}}$ \\ Indonesia \\ *Corresponding author: \\ Arum Etikariena \\ Industrial and Organizational Psychology Department \\ Faculty of Psychology, Universitas Indonesia \\ Jl. Lkr. Kampus Raya, Depok, Jawa Barat \\ Indonesia, 16424 \\ Tel.: +62 217270004 \\ Email: arum.etikariena@ui.ac.id
}

${ }^{a}$ Faculty of Psychology, Universitas Indonesia, Depok, Indonesia; ${ }^{b}$ Department of Industrial and Organizational Psychology, Faculty of Psychology, Universitas Indonesia, Depok, 


\title{
The Influence of Psychological Empowerment on Turnover Intention through Appreciative Inquiry Workshop for Employee at Division X Company X
}

\begin{abstract}
Many previous studies have explained that high turnover rate will reduce company productivity. Turnover as counter-productive behavior for the whole component of the company. Based on the initial interviews, it was identified that employees of Division X Company $\mathrm{X}$ felt less competent to face internal and external changes, so they decided to leave the company or showed stagnant work performance. This study aims to determine the influence of psychological empowerment on the turnover intention with the appropriate intervention program to improve psychological empowerment for employee at Division X. Based on literature review, the turnover intention was influenced by psychological empowerment. The study was conducted on 103 employees of Division X. Turnover intention was measured through turnover intention questionnaire $(\alpha=0.83)$ and psychological empowerment was measured through psychological empowerment questionnaire $(\alpha=0.74)$. The result using linear regression showed psychological empowerment has a significant negative correlation to turnover intention $\left(R^{2}=3,8, B=-\right.$ $.195, p<.05)$. Based on this result, the researcher determines Appreciative Inquiry Workshop would be appropriate as an intervention. The evaluation of HR teams about the intervention program indicated that appreciative inquiry workshop was appropriate to be implemented as an additional program of current company employee development.
\end{abstract}

Keywords: appreciative inquiry, psychological empowerment, turnover intention, workshop

\section{Introduction}

Employee turnover had become one of the counter-productive behaviors and an obstacle for the company (Landy \& Conte, 2013). Literature explained high turnover rate would reduce productivity (Aamodt, 2010), work-climate (Ferguson, 1986) and company internal stability (Landy \& Conte, 2013). Turnover behavior can be predicted through turnover intentions. The turnover intention was defined as the tendency of voluntary employee withdrawal, terminating the term of the employment contract, leaving the company and looking for other job opportunities after occupying a certain position (Lee et al., 2012).

High turnover also found in one of the multinational pharmaceutical companies, including Company $\mathrm{X}$. Focused on Division $\mathrm{X}$ which showed highest turnover rate compared with others division of the company. The pre-assessment results and and the company's data showed that in the last two years Division X had decreased revenue attainment due to the company's external conditions. This condition made the company to decide a policy to lay off three employees. The lay off caused insecurity in other employees, which resulted in 17 employees resigning voluntarily. Company data also showed that in 2016, there was $14,29 \%$ employee that decides to resign voluntarily. This percentage was an increase from 2015 , in which only 9,24\% employees decided to resign voluntarily. The result of company exit interview showed that some of the reasons that made employee gave their resignation were changes in organizational climate, such as lack of autonomy in doing action work, the feeling that they had less influence to the success of the business process, and lack of information regarding policy, work and company business processes. 
In-depth interviews with 15 employee representative position of manager, supervisor, associate manager and staffs showed that employees intend to look for opportunities in other companies if they get a better offer regarding benefits or incentives. This intention was felt because of internal works situations, poor communication with leader, less autonomy to perform work process in different ways, and the feeling of incompetence to achieve the target. These conditions affected employees' confidence in performing their duties, so their motivation to show the best performance were stagnant or decline. They only work because it was an obligation. Based on a literature study, lack of autonomy in doing action work, the feeling less influence to the success of the business process, less autonomy to perform work process in different ways, and the feeling of incompetence to achieve the target. These issues were related to psychological empowerment dimensions that are meaning, competence, selfdetermination, and impact.

In some literature, turnover intention affected by two group factors that are external and internal factors (Garkovich, 1994). One of an internal factor related to employee turnover intentions is psychological empowerment (Islam, Munawar, \& Bukhari, 2015; Griffeth, Hom, \& Gardner, 2000; Meyerson \& Kline, 2008; Nawawi, Hussain, Ramli, Sulaiman, \& Razali, 2015). Psychological empowerment knew as a motivational construct. Spreitzer (1995) define Its manifested into four cognitions dimensions such as meaning, competence, selfdetermination, and impact. He also stated psychological empowerment was needed so individuals could feel that they had power and control on the work that they were responsible for (Spreitzer, 1995).

Meaning is defined as work goal or purpose value of their work judged by its relation to individual standards (Thomas \& Velthouse, 1990). Competence has the same concept to selfefficacy. Competence is defined as the individual's belief in their capability to perform job activity or work with their skill or competencies. Self-determination is defined as the autonomy or discretion of the individual in choosing how to do the work. Self-determination shows individual's sense of having a choice in their job action. Last, Impact refers to the degree to which an individual affects the work or organization such as strategic, administrative or operating outcomes at work (Spreitzer, 1995). Seibert (2011) in his metaanalysis study explains the existence of psychological empowerment caused two categories of consequences. First attitudinal consequences are job satisfaction, organizational commitment, tension and turnover intention. Second, behavioral consequences such as task performance, organizational citizenship behavior, and innovative behavior.

Employees with high psychological empowerment demonstrate satisfaction and intention to stay in the organization (Islam et al., 2015; Griffeth, et al., 2000; Meyerson \& Kline, 2008; Nawawi et al., 2015) and show more positive performance (Meyerson \& Kline, 2008). Islam et al. (2015) in his research proved that psychological empowerment affected turnover intention directly and indirectly. Employees with high psychological empowerment have positive thoughts about their work that ultimately affects employee satisfaction, loyalty, performance, how they deliver services, organizational citizenship behavior and employee retention (Bester, Stander, Van Zyl, 2015). Another study by Nawawi et al. (2015) showed that there was a negative relationship between psychological empowerment with turnover intention within the company. When employees feel they mean something to the company, it will strengthen them to stay in the company.

Based on description above, psychological empowerment could be a potential key to decrease turnover intention. The result of the initial diagnosis interviews also highlighted the 
importance of psychological empowerment to turnover intention. However, the influence of psychological empowerment on turnover intention in Division $\mathrm{X}$ employee should be confirmed. With the key points stated above, the hypothesis proposed in this research is:

\section{Hypothesis: Psychological empowerment affects turnover intention}

Confirming the hypothesis before designing the intervention would enable a more effective and appropriate intervention to decrease turnover intention. The research result would then serve as a base to design intervention program as an effort to decrease turnover intention through the increase of psychological empowerment level.

Psychological empowerment could be improved by several ways. Thomas and Velthouse (1990) described that psychological empowerment could be improved through two factors, changing work environment (external factor) and changing individual interpretation about their work environment (internal factor). Individual interpretation change requires individual active action to change what he/she believed by giving a new point of view or new concept. Seibert (2011) in his research also showed that psychological environment was affected by two factors, contextual (external) and individual factor (internal). Individual factors related to psychological empowerment is positive self-evaluation traits. Positive self-evaluation traits defined as how individuals perceive themselves and their environment. Individuals need to change their perspective on self and their work environment including in doing their job activity. It requires self-awareness and individual concern.

Employees could change their self-perspective using an approach called Appreciative Inquiry (Copperider \& Whitney, 2005). Appreciative Inquiry is a positive psychological approach that could direct employees to realize the strength that they have. This approach can be used to explore individual uniqueness and ability (Copperider \& Whitney, 2005). This approach would be beneficial since people who are aware of their strength will contribute more to their environment (Copperider \& Whitney, 2005). In the context of this research, employees could give more contribution to the company.

Appreciative is often equated with other terms such as (1) valuing, which is a gift; (2) prize, which is a gift or a gift; (3) esteeming, which is an award; (4) honoring, which is a tribute to (Cooperider \& Whitney, 2005). The inquiry is defined as the process of searching or exploring, digging by questioning so that potential and positive possibilities of individuals can be explored. Inquiry can be paired with other terms: (1) discovery, which is the invention; (2) search, which is a search; (3) systematic exploration, which is a systematic exploration; (4) study, which is learning. Appreciative inquiry approach involves groups of individuals to give questions to each other and explore their capacity and potential. Appreciative inquiry differs from traditional problem-solving. Problem-solving focuses on the wrong, the negative and needs to be improved. Unlike the case of appreciative inquiry approaches that emphasize more on the positive things possessed by individuals who may not have been realized by the individual. Appreciative Inquiry approach involves five stages or basic steps: Discover, Dream, Design, Destiny (Cooperrider and Whitney, 2005). Appreciative inquiry approach becomes a bridge to change individual perception so they could be more positive to self and its environment.

In overcoming organizational problems related to the improvement of psychological empowerment to reduce the level of employee turnover intention. The selected interventions are a workshop as a preliminary intervention. The workshop became the choice of early 
interventions for needs analysis and answered questions about training needs and continued development. Workshops can be activities that precede other forms of intervention activities. Workshop as one kind of method by involving groups of people with interests and background more or less the same. The selected interventions are appreciative inquiry workshop focused on increasing psychological empowerment on employee. The workshop aims to find an initial solution for solving individual or group problems. Participants will solve problems by joint discussion and produce work or product (Laird, 1993) for their action plan.

\section{Methods}

This research used a quantitative approach. A quantitative approach is an approach to explore specific information related to research problems by quantifying the data obtained into the form of numbers which are then processed by statistical calculation to obtain the relationship between research variables (Kumar, 2012). This method selected because the type of data obtained is a variable that can be quantified. Researchers aim to see the score of each variable, test the relationship between research variables.

\section{Participant}

This research was conduct on Division X Company X employees. The respondents were permanent employees that had one year of tenure in minimum, with varying position level such as staff, supervisors, associate manager and manager. The population of this study is 216 employees. By using Slovin Technique to determine the number of samples, we calculated 144 respondents for sample target. The sampling technique that used in this research is simple random sampling. Online Questionaire link survey were sent to email address of each respondent that selected randomly. From 165 online questionnaire distributed by researchers, 108 filled out the questionnaire, but only 103 data could be processed.

\section{Research Design}

This research design used correlational design. The design is used to demonstrate the relationship between two variables (Kumar, 2012) under actual conditions or without manipulation of the variables involved (Faenkel \& Wallen, 2008). The research variable is turnover intention as the dependent variable and psychological empowerment as the independent variable. As an effort to improve organizational effectiveness can be carried out planned changes as part of organizational development activities. Therefore, to provide practical application to the organization, the researchers also used the type of action research model. The aim of action research approach is assisting organizations in developing knowledge and implementing change as a tool for applying the study results (Cummings \& Worley, 2015). This type of research focuses on data collection and diagnosis before planning and implementing interventions.

\section{Measures}

This study used two measurements. First, the turnover intention was measured by turnover intention measurement designed by Mobley, revised by Lee (2012) and adapted to Indonesian language. The turnover intention in this measurement measured: 1) turnover intention strength; 2) motivational strength to search for other jobs; 3 ) the extent of influence from the availability number of external job opportunities, and 4) the strength of intention to leave the current job. The measurement consisted of 10 items, with a 5-point Likert scale (strongly disagree, disagree, average, agree, strongly agree). A higher value indicates a higher turnover intention. From 10 items there are two unfavorable questions: "I will not quit my job even if the company has changed" and "I will not leave the current company if another company 
actively offers a position. This measurement has good reliability, with Cronbach Alpha coefficient $=.83$.

Secondly, the psychological empowerment was measured using Psychological Empowerment Scale from Spreitzer (1995) that was adapted to Indonesian language. It measured four dimensions of psychological empowerment: meaning, competence, self-determination, and impact. There were 12 items within this measurement, the four dimensions are represented in each of the three points of the statement, with five-point Likert scale (strongly disagree, disagree, average, agree, strongly agree). A higher score indicates a higher psychological empowerment level. This measurement also has decent reliability, with Cronbach Alpha coefficient $=.74$.

\section{Procedure}

The procedure in this study referred to the general model of planned change (Cummings \& Worley, 2015). The general model of planned change consisted of four stages of activity consist of entering and contracting, diagnosing, planning and implementation and evaluation and institutionalization. The first stage, entering and contacting, researchers met HR Manager and HR BP of the company to establish cooperation, get approval from management and get an overview of the organizational problem in Company X. Secondly, researchers started the diagnosing stage. The diagnosis process focuses on understanding the problems that occur within the organization; Researchers analyzed secondary data such as company profile, company personal domestic, employee engagement survey and company annual report. From secondary data, the researcher found Division X had highest turnover rate compared with other division in Company X and the turnover rate on Division X increase from 2015 to 2016. Diagnosing stage continued by online questionnaire survey. The online survey lasted for two weeks. After get result of diagnosing stage, researchers arrange intervention program based on the result. This stage entered into planning and implementing change as the third stage. The intervention program designed to resolved Division $\mathrm{X}$ problem related to psychological empowerment and turnover intention. The intervention program consists of three phases, workshop activity, team sharing session and reflection meeting. Researcher proposed this intervention design to HR Team. HR BP is giving feedback to intervention design to fit in with the internal condition. The researcher also prepared evaluation package that can be used for evaluating appreciative inquiry workshop. The evaluation consists of two-level which are the reaction level and the learning level.

\section{Data Analysis}

The Method used to analyze quantitative data from turnover intention and psychological empowerment questionnaire. The data were analyzed using IBM SPSS for Windows program. Statistical techniques by descriptive analysis and linear regression were used in data processing.

\section{Results}

Normality test using Kolmogorov Smirnov showed that the data is normally distributed. Normality data is used because one of the prerequisites of testing with parametric statistics is normally distributed data. Therefore, in the study, the calculation of advanced statistics will be used parametric statistics.

The result from Linear regression test showed that psychological empowerment significantly affects the turnover intention. The calculation with simple linear regression also showed $\mathrm{R}^{2}=$ .038 , which means that $3.8 \%$ turnover intention variables can be explained by psychological 
empowerment and variations in turnover intention also influenced by others variable $(92,6 \%)$ which is not discuss in this research $\left(R^{2}=3.8, b=.-195, p<.05\right)$.

Beside linear regression, researchers divide turnover intention and psychological empowerment into two categories. High level of turnover intention and psychological empowerment (if individual score higher than mean) and low level of turnover intention and psychological empowerment (if individual score is higher than mean). Researchers use empirical means to compare the individual score of respondents with their groups. Researchers will compare the score of individuals with group members from the total respondent amount 103 people. High and low category uses to determine the priority of intervention participants with high turnover intentions and low psychological empowerment. Table 1 showed a general description of turnover intention and psychological empowerment respondent.

Table 1.

Turnover Intention and Psychological Empowerment Category

\begin{tabular}{ccccc}
\hline Category & \multicolumn{2}{c}{ Turnover Intention } & \multicolumn{2}{c}{ Psychological Empowerment } \\
& $\mathrm{f}$ & $\%$ & $\mathrm{f}$ & $\%$ \\
\hline High & 55 & $53,40 \%$ & 56 & $54,37 \%$ \\
Low & 48 & $46,60 \%$ & 47 & $45,63 \%$ \\
\hline
\end{tabular}

The data showed that the respondents have high turnover intention $(\mathrm{M}=27.43, \mathrm{SD}=6.25)$ and high psychological empowerment $(M=47.44, S D=4.17)$.

With the confirmation of the effect of psychological empowerment to turnover intention, an appreciative inquiry intervention was designed with the aim of decreasing turnover intention through psychological empowerment increase. The design is described in a series of intervention activities as follows:

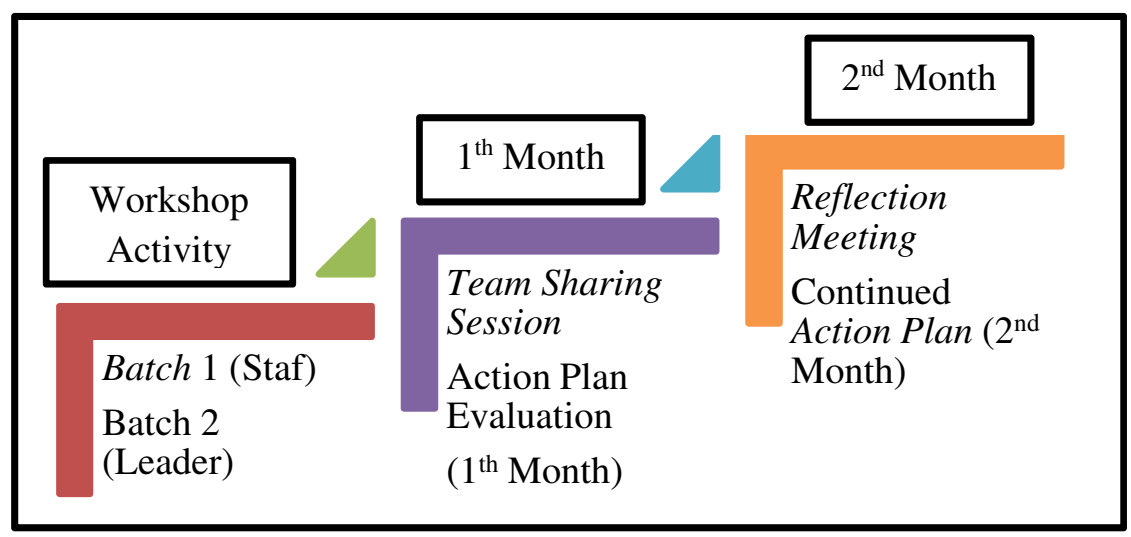

Figure 1. Stage of Intervention

Appreciative inquiry workshop also was given to the employee's direct leader with low psychological empowerment. The aims of the workshop in leader level are applying the same approach to solving when facing the task in the team for leader and their subordinates. This intervention design implemented as an additional program of current company employee development. The company has a monthly sharing program that is conducted by each working team. The company hopes the concept of problem-solving through this positive approach can be applied continually. The results of the action plan later can be applied to employee personal development. Furthermore, Table 2 showed the outline of the series that was seen in Figure 1. 
Table 2.

Intervention Series

\begin{tabular}{|c|c|c|c|}
\hline Intervention Series & Activity & Purpose & Parties \\
\hline $\begin{array}{l}\text { Workshop Positive } \\
\text { Me Batch } 1 \& 2 \\
\text { (Leader \& Staff) }\end{array}$ & $\begin{array}{ll}\text { 1. } & \text { Pre-activity } \\
\text { 2. } & \text { I Know My Self (Discover) } \\
\text { 3. } & \text { I Know My Best (Discover) } \\
\text { 4. } & \text { Share Your Dream (Dream) } \\
\text { 5. } & \text { Positive Me for Positive Result } \\
\text { 6. } & \text { I'm Empowered (Design) } \\
\text { 7. } & \text { Design Yours and Lets Moved } \\
\text { (Design \& Destiny) } \\
\text { 8. } & \begin{array}{l}\text { Post Activity (Debrief and } \\
\text { Evaluation) }\end{array} \\
\end{array}$ & $\begin{array}{l}\text { Introduce Appreciative } \\
\text { Inquiry approach } \\
\text { Afirmative topics : My Job } \\
\text { desk and Job Activity }\end{array}$ & $\begin{array}{l}\text { Researcher, HR, } \\
\text { respondents }\end{array}$ \\
\hline $\begin{array}{l}\text { Sharing Session } \\
\left(1^{\text {th }} \text { Month }\right)\end{array}$ & $\begin{array}{l}\text { - The staff submits action plan that have } \\
\text { been prepared in the workshop } \\
\text { - Discussion of actions that have or have } \\
\text { not been done effectively } \\
\text { - Evaluation of unsuccessful action plans } \\
\text { Discuss other affirmative themes through } \\
\text { the AI approach if necessary }\end{array}$ & $\begin{array}{l}\text { - } \\
\text { - Action Plan Evaluation } \\
\text { nection Modification if } \\
\text { - } \quad \text { Leader confirms and } \\
\text { knows the } \\
\text { implementation of } \\
\text { staffs' action plan }\end{array}$ & Leader \& Team \\
\hline $\begin{array}{l}\text { Reflection Meeting } \\
\left(2^{\text {nd }} \text { Month }\right)\end{array}$ & 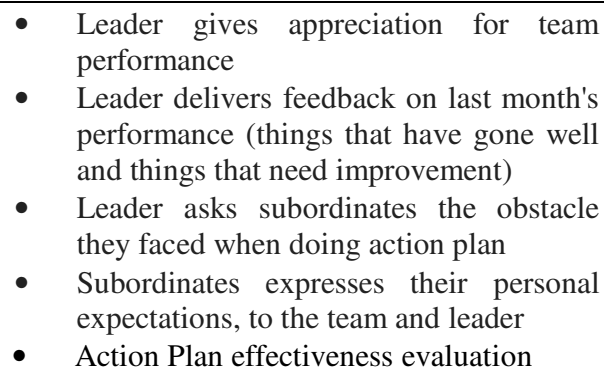 & $\begin{array}{l}\text { Action Plan Evaluation } \\
\text { Stage } 2\end{array}$ & $\begin{array}{l}\text { Leader, HR \& } \\
\text { Team }\end{array}$ \\
\hline
\end{tabular}

The approach of learning method for the implementation of intervention will be based on experiential learning theory (ELT) developed by David Kolb. Experiential Learning Theory suggests that learning is a dynamic cycle involving four stages of concrete experience, reflective observation, abstract conceptualization and active experimentation. The approach of learning method also be directed to adult learning theory (andragogy). Principles that are important to understand in adult learning and to be considered in the preparation of learning methods are: (1) Participants are given the opportunity to use their knowledge and experience in each situation, (2) Participants are given opportunities in decision making, (3) Giving participants the opportunity to learn independently, (4) Participants are given strengthening to participate in group activities, (5) the time of the activity is designed as efficiently as possible by starting and ending the training session on time and providing an understanding of the importance of doing the activity. The intervention series was socialized with Human Resources Team of the company. The purpose of socialization activities is to get feedback and evaluation from the company as an effort to create an intervention program by the needs and conditions of the company. This activity was attended by the Human Resources Company's Bussiness Partner and Associate Manager Training and Development. In general there were several suggestions given by Human Resources of the company. First, giving a role model is important to enhance the effectiveness of intervention program. Second, some of the psychological term made participant feeling difficult to fully understand the intervention. For example "appreciative inquiry" is an abstract concept for the participant. HR suggest to use common terms to deliver the intervention. The use of this term can be started by defining the theme of the workshop. Suggested themes such as Let's be More Positive or Positive Me. Third, workshop materials are made as simple as possible so that participants can more easily understand the purpose of holding activities and can benefit from the activity, Fourth, At the 
beginning of the activity can be given the participants' self-introduction session through simple applicative personality questionnaires. This stage is to help if participants are difficult to dig up their achievements in the second session. This session also facilitating when the participant feels did not have a certain achievement in his job last few years.

\section{Discussion}

This research found that psychological empowerment affect intention turnover of employees of Division X Company X. This research in line with previous research conducted by Islam (2015), Griffeth et al. (2000), Meyerson and Kline (2008) and Nawawi (2015) show that employees with high psychological empowerment will show satisfaction and persistence intention in higher organizations. Bester et al. (2015) in his research also showed that employees with high psychological empowerment tend to have positive thinking about their work that will ultimately affect the increase in satisfaction, loyalty, performance, increase organizational citizenship behavior and desire to stay within the organization.

The results showed that psychological empowerment variables could explain $3.8 \%$ turnover intention variance, while the remaining $96.2 \%$ is influenced by other variables not explained in this research. The small effect of psychological empowerment opens the discussion of the possibility of other variables that moderated or mediated the relationship between psychological empowerment and turnover intention. Islam et al. (2015) in his research explains the role of mediation in part of the affective commitment in the relationship between turnover intentions and psychological empowerment. Some research on organizational commitment (Landy \& Conte, 2013, Lee et al., 2012) and job satisfaction (Bester, 2015) prove that these two variables are directly related to employee turnover intentions while employees with high psychological empowerment have positive thoughts about their work. The positive thoughts would ultimately affect employee satisfaction, loyalty, performance and the way employees to provide services (Bester et al., 2015). Others study from Bordin, Bartram \& Casimir (2007) explained that psychological empowerment could increase organizational commitment and job satisfaction. Wang and Lee (2009) in his research also explained that the dimensions of psychological empowerment related to job satisfaction perceived by employees.

The relatively small effect of psychological empowerment on employee turnover intentions implied that Appreciative Inquiry should only serve as a supplementary program to assist other programs within the organization. In this case, the workshop design is incorporated into the Sharing Session Team program which becomes a monthly routine agenda in the company. The relatively small effect can also be explained in Seibert's research (2011) shows that external factor (contextual) have greater influence than individual factors on psychological empowerment. External factors affecting psychological empowerment such as high performance managerial practice (e.g open sharing of information, opportunities to participate in decision-making, training and development opportunities and compensation), sociopolitical support (e.g organizational climate, positive employee perceptions of the company and level of organizational trust) and supportive leadership (trust between leaders and subordinates).

Sharing session team program was selected since Bordin and Bartram (2007) concluded in his research that social support from supervisors (supervisory support) is positively associated with the psychological empowerment of subordinates. Leaders play an important role in improving psychological empowerment. Perceptions of supervisor support are a factor that plays a role in improving employee empowerment. Therefore, it is necessary that leaders are 
informed on the importance of psychological empowerment. Supervisor is expected to take actions that can enhance their subordinate psychological empowerment, such as providing positive feedback, social support and delegation of tasks that are part of the team's worksharing program.

There are suggestions based on the result and discussion research such as ensuring collecting data through an organizational diagnostic questionnaire as an initial diagnosis (pre preliminary study) for identifying organizational problems can be done before advance diagnosing. This preliminary data will enrich and sharpen organizational problems found, for example by using the Organizational Blockage questionnaire, Organizational Climate or Organizational Diagnosis Questionaire (ODQ). Secondly, considering moderator variables such as organizational commitment, job satisfaction or organizational citizenship behavior to strengthen the relationship between psychological empowerment and turnover intentions. Last, using continuous intervention method between contextual factor (external individual) and individual factor (internal) to maximize the improvement of psychological empowerment variable as a variable that plays a role in decreasing employee turnover intention.

There are several limits in this study. First, there was no pre preliminary study using organizational diagnostic questionnaire. This condition cause early stages of organizational identification problems only diagnose through the company's secondary data and interviews. Second, the Employee Opinion Survey questionnaire contains four questionnaires at once, because the study was conducted simultaneously with the study of another variable from the different researcher. The relatively large number of statement items might make the respondents to feel exhausted and to lose concentration since some of the items seem similar and repetitive. Third, the timeline to conduct design intervention is not in line with company schedule and fourth, respondents who have high turnover intention level and low psychological empowerment are mostly respondents with work areas outside Jakarta. This conditions causing the last stages in action research that is evaluation and institutionalization stages cannot be done optimally.

\section{References}

Aamodt, M. G. (2010). Industrial/organizational psychology: An applied approach (6th ed.). Belmont, CA: Cengange Learning.

Bester, J., Stander, M.W., \& Van Zyl, L.E. (2015). Leadership empowering behaviour, psychological empowerment, organizational citizenship behaviours and turnover intention in a manufacturing division. Journal of Industrial Psychology.41(1).

Bordin, C., Bartram, T., \& Casimir, G. (2007). The antecedents and consequences of psychological empowerment among Singaporean IT employees. Management Research News. 30 (1).

Cohen, R. J, \& Swedlik, E. 2009. Psychological Testing and Assessment: An Introduction to Tests and Measurement 7th ed. Illinois: McGraw-Hill

Conger, J. A., \& Kanungo, R. N. (1988). The empowerment process: Integrating theory and practice. Academy of Management Review, 13, 471-482.

Cummings, T. G., \& Worley, C. G. (2015). Organization development and change. Stamford, CT: Cengage learning.

Cooperrider, D. L. \& Whitney, D. (2005). A Positive Revolution in Change: Appreciate Inquiry. California: Berret-Koehler.

Faenkel, J.R., \& Wallen, N.E. (2008). How to Desain and Evaluate Research in Education. New York: McGraw-Hill

Ferguson, G. H. (1986). Distinguishing Voluntary from Involuntary, Nurse Turnover. Nursing Management, 17(12), 43-44. doi: $10.1097 / 00006247-198612000-00018$

Garkovich, L., \& Greider, T. (1994). Landscape the social construction of nature and the environment. Rural Sociology, $59(1), 1-24$.

Griffeth,R.W.,Hom,P.W. \& Gartner,S.(2000), A meta-analysis of antecedents and correlates of employee turnover: update, moderator tests, and research implications for the next millennium, Journal of Management, 26 (3), 463-488.

Gravetter, F. J. \& Forzano, L. (2012). Research Methods for the Behavioral Sciences, $4^{\text {th }}$ edition. Canada : Wadsworth Pub. 
Islam, T., Munawar, M.K., \& Bukhari,F.H. (2015). The role of organizational learning culture and psychological empowerment in reducing turnover intention and enhancing citizenship behavior. The Learning Organization. 23(2/3). $156-169$

Kaplan, R. M. \& Saccuzzo, D.P. (2005). Psychological testing principles, application, and issues $\left(6^{\text {th }}\right.$ Ed). Canada: Wadsworth Cengage Learning

Kumar, R. (2012). Research Methodology: A Step-By-Step Guide For Beginners (2nd ed.). London: Sage Publications Ltd.

Landy, J. F., \& Conte, J.M. (2013). Work in the 21st. Wiley: San Diego State University.

Laird, D. (1993). Approaches to training and development (2nd ed.). Massachusetts: Addison-Wesley.

Lee, D., Li, M., \& Chen, M.(2012). Empirical study on the Influence among corporate sponsorship, organizational commitment, organizational cohesiveness and turnover intention. Journal of Management and Sustainability. 2(2)

Meyerson, S.L., \& Kline, T. (2008). Psychological and Environmental Empowerment Antecedents and Consequences. Leadership and Organizational Journal. 29, 444-460.

Mobley, W.H. (1977). Intermediate linkages in the relationship between job satisfaction and employee turnover. Journal of Applied Psychology, Vol. 62, No. 2, 237-240. Diakses dari ProQuest database.

Mobley, W. H., Horner, S. O., \& Hollingsworth, A. T. (1978). An evaluation of precursors of hospital employee turnover. Journal of Applied Psychology, 63(4), 408-414. http://dx.doi.org/10.1037/0021-9010.63.4.408

Mobley, W.H., Griffeth, R.W., Hand, H.H., \& Meglino, B.M. (1979). Review and conceptual analysis of the employee turnover process. Psychological buleetin, 86(3), 493.

Nawawi, W, N., Hussain, F, M., Ramli, N., Sulaiman, W, N., \& Razali, N, M. (2015). Psychological Empowerment Influence the Retention Intentions of 5-Star Rated Spas' Employees. Journal of Applied Environment and Biological Sciences. 5(6s), 95-99.

Robbins, S. P., \& Judge, T.A. (2013). Organizational behavior (15th ed). USA: Pearson Education, Inc.

Seibert, S.E., Wang, G., \& Courtrigth, S.H. (2011). Antecedents and consequences of psychological and team empowerment in organization: A meta-analytic review. Journal of Applied Psychology, 96(5), 981-1003.

Spreitzer, G, M. (1995). Psychological Empowerment in the Workplace: Dimensions, Measurement, and Validation. The Academy of Management Journal. 38(5). 1442-1465. Retrieved from http://about.jstor.org/terms Academy of Management Journal.

Spreitzer, G. M. (2008). Taking stock: a review of more than twenty years of research on empowerment at work. in J. Barling \& C. L. Cooper (Eds.), Handbook of organizational behavior (54-72). Thousand Oaks, CA: Sage.

Thomas, K.W., \& Velthouse, B.A. (1990). Cognitive elements of empowerment: an "interpretive" model of intrinsic task motivation. The Academy of Management Review, 15(4), 666-681.

Wang, G., \& Lee, P.D. (2009). Psychological Empowerment and Job Satisfaction: an analysis of Interactive Effect. Group \& Organization Management (34). doi: 10.1177/1059601108330089. 